\title{
HRVATSKI URED ZA DOI I SUSTAV DOI-HR
}

\section{CROATIAN DOI OFFICE AND DOI-HR SYSTEM}

\author{
Danijela Getliher \\ Nacionalna i sveučilišna knjižnica u Zagrebu \\ dgetliher@nsk.hr \\ Silvana Šehić \\ Nacionalna i sveučilišna knjižnica u Zagrebu \\ ssehic@nsk.hr

\section{Lucija Martinić} \\ Nacionalna i sveučilišna knjižnica u Zagrebu \\ lmartinic@nsk.hr
}

UDK / UDC [004+001+655+02]: 615.07

Stručni rad / Professional paper

Primljeno / Received: 13. 9. 2019.

Prihvaćeno / Accepted: 26. 11. 2019.

\section{Sažetak}

Cilj. Cilj je rada prikazati ciljeve i proces uspostave Hrvatskog ureda za DOI Nacionalne i sveučilišne knjižnice u Zagrebu, razvoj i svojstva Sustava DOI-HR te dosadašnji rad i postignuća Ureda.

Pristup/metodologija/dizajn. U radu se deskriptivnom metodom opisuju osnovna svojstva identifikacijskog sustava za DOI, njegove registracijske agencije Crossref $i$ Crossrefovog registracijskog ureda u Republici Hrvatskoj - Hrvatskog ureda za DOI. Uz analizu podataka zabilježenih krajem 2018. godine o tekućim hrvatskim znanstvenim i znanstveno-stručnim časopisima prikazuju se razlozi osnivanja, kao i pogodnosti članstva ostvarenog posredništvom Ureda. Rad obuhvaća prikaz radnog procesa Hrvatskog ureda za DOI, analizu i opis Sustava DOI-HR, njegove strukture, svrhe, funkcionalnosti, modele suradnje i načine dostave metapodataka.

Rezultati. U radu je detaljno i pregledno prikazana uspostava nove usluge Nacionalne i sveučilišne knjižnice u Zagrebu. Ukazuje se na važnost osnivanja Hrvatskog ure- 
da za DOI pri Nacionalnoj i sveučilišnoj knjižnici u Zagrebu. Opisuje se novi Crossrefov model djelovanja nacionalnog ureda za DOI kojim se ostvaruje značajna financijska ušteda te pružaju ostale pogodnosti za nakladnike koji uslugu koriste posredništvom Hrvatskog ureda za DOI i sustava DOI-HR kao što je usluga provjere izvornosti rada (Similarity Check), tehnička podrška pri dodjeli i registraciji DOI-ja, trajna pohrana registriranih članaka i sveščića, održavanje trajnosti DOI-ja te poluautomatizirano uvrštavanje članaka u Hrvatsku nacionalnu bibliografiju, pohranu i objavu na portalu Digitalne zbirke Nacionalne i sveučilišne knjižnice u Zagrebu.

Praktična primjena. Rad je namijenjen široj knjižničarskoj zajednici i nakladnicima koji koriste ili žele koristiti uslugu dodjele i registracije DOI-ja posredništvom Ureda, kao i drugim nacionalnim i sveučilišnim knjižnicama koje promišljaju o načinima osnivanja i djelovanja nacionalnog ureda za DOI.

Originalnost/vrijednost. Rad opisuje uspostavljanje Hrvatskog ureda za DOI, nove usluge Nacionalne i sveučilišne knjižnice u Zagrebu, jedine nacionalne i jedne od tri sveučilišne knjižnice u svijetu koje primjenjuju novi Crossrefov model zastupanja nakladnika (Sponsoring Organisation). Prikazuje se potreba i način jedinstvenog i objedinjenog pružanja ove vrste usluge na nacionalnoj razini čiju je vrijednost prepoznalo i podržalo Ministarstvo znanosti i obrazovanja Republike Hrvatske. Opisan je jedinstveni sustav, Sustav DOI-HR, izgrađen za potrebe rada i djelovanje Ureda koji osim pružanja podrške pri izračunu/dodjeli i registraciji DOI-ja te dostavi metapodataka i objekata omogućuje i povezanost s drugim sustavima i istovremeno ostvarivanje drugih zadaća nakladnika i Nacionalne i sveučilišne knjižnice u Zagrebu kao što su dostava i zaprimanje obveznog primjerka mrežne građe, njezino uvrštavanje u nacionalnu bibliografiju i u digitalnu knjižnicu.

Ključne riječi: Crossref, DOI, Hrvatski ured za DOI, identifikatori, Sustav DOI-HR.

\section{Abstract}

Purpose. The aim of this paper is to present the goals and the process of establishing the Croatian DOI Office as part of the National and University Library in Zagreb, the development and characteristics of the DOI-HR System as well as the work and the accomplished achievements of the Office.

Approach/methodology/design. The paper uses the descriptive method to explain the basic characteristics of the DOI identification system, its registration agency the Crossref and the Crossref registration office in the Republic of Croatia - the Croatian DOI Office. Along with the analysis of the statistical data recorded at the end of 2018 on the current Croatian scientific and professional journals, the paper presents the reasons for founding and the benefits of the membership obtained through the mediation of the Office. The paper mainly focuses on the work process and procedures of the Croatian 
DOI Office, the analyses and description of the DOI-HR System, its structure, purpose, functionalities, collaborations models, and metadata submission methods.

Findings. The paper presents in detail the establishment and the activities of the new service of the National and University Library in Zagreb. It shows the necessity of the establishment of the Croatian DOI Office at the Library. The paper describes a new Crossref model operated by the national DOI office that provides significant financial savings and broad range of other benefits for publishers who use the service through the Croatian DOI Office and DOI-HR System, such as Similarity Check services, technical support for assigning and registering DOIs, permanent storage of registered articles and all-rounders, maintenance of permanence of DOI, semi-automatized inclusion of articles in the Croatian National Bibliography and publication on the portal Digitalne zbirke Nacionalne i sveučilišne knjižnice u Zagrebu (Digital Collections of the National and University Library in Zagreb).

Practical implication. The paper is intended for the wider library community and publishers who use or want to use the Croatian DOI Office registration service and other national and university libraries that consider establishing a national DOI office.

Originality / value. The paper describes the establishing of the Croatian DOI Office, a new service of the National and University Library in Zagreb, the first national and one of the three university libraries in the world that use the new Crossref model of representing publishers (Sponsoring Organisation). Furthermore, the value of and the need for this unique type of service, that the Croatian Ministry of Science and Education has recognized too, are presented. The paper describes a unique system, the DOI-HR System, developed especially for the needs of the Office by the National and University Library in Zagreb. The System allows easier constructing and registering DOIs for the publishers, submitting metadata and objects and provides connectivity to other systems, and, at the same time, fulfills other tasks of the publishers and the national library, such as delivering and receiving of the legal deposit of online resources and their inclusion in the national bibliography and the digital library.

Keywords: Croatian DOI Office, Crossref, DOI, DOI-HR System, identifiers.

\section{Uvod}

Dodjela jedinstvenih trajnih identifikatora rezultatima znanstvene produkcije omogućuje brzo i jednostavno pronalaženje te izravni pristup radovima na internetu. Zbog takvih je svojstava i trajni identifikator DOI (Digital Object Identifier) postao važan element za znanstveno nakladništvo u digitalnom okruženju. U zadnjih desetak godina u Hrvatskoj je nekoliko različitih znanstvenih institucija pokretalo inicijative za osnivanjem ureda za DOI u Republici Hrvatskoj. Sama 
Nacionalna i sveučilišna knjižnica u Zagrebu svoj interes za osnivanjem Ureda Ministarstvu znanosti i obrazovanja Republike Hrvatske iskazala je u više navrata 2013., 2015. te 2017. godine kada je Ured i osnovan.

Hrvatski ured za DOI ${ }^{1}$ od tada djeluje pri Nacionalnoj i sveučilišnoj knjižnici u Zagrebu u Odjelu Bibliografsko središte, proces Identifikatori kao Crossrefov ${ }^{2}$ registracijski ured. Svrha osnivanja ureda je ostvarenje pravovremene primjene trendova razvoja identifikacijskih sustava i izvršavanje zadataka nacionalne knjižnice, postizanje uštede hrvatskoj nakladničkoj i znanstvenoj zajednici, postizanje šireg obuhvata publikacija i radova hrvatskih znanstvenika s dodijeljenim DOIjem, postizanje njihove veće dostupnosti i vidljivosti u svjetskom istraživačkom prostoru čime se olakšava postizanje sveobuhvatnosti okupljanja nacionalne znanstvene produkcije, olakšava izgradnja digitalne knjižnice, prikupljanje obveznog primjerka i izrada nacionalne bibliografije. Cilj djelovanja ureda je posredovanje između hrvatskih nakladnika i registracijske agencije Crossref pri dodjeli i registraciji DOI-ja ${ }^{3}$ za znanstvene i znanstveno-stručne časopise te za njihove članke, sveščiće i godišta.

Ured je osnovan uz potporu Ministarstva znanosti i obrazovanja Republike Hrvatske, a potpora se odnosi na pokrivanje troškova dviju godišnjih članarina godišnje članarine u Crossrefu i godišnje članarine za korištenje usluge provjere izvornosti rada (Smilarity Check). Ovim dvjema članarinama pokriveni su troškovi članstva u Crossrefu svim nakladnicima koji uslugu koriste posredništvom Ureda. Osim članarina, Ministarstvo znanosti i obrazovanja Republike Hrvatske pokriva i troškove pojedinačnih registracija DOI-ja za članke godišta u tekućoj kalendarskoj godini.

Administrativno-pravno-tehničku podršku osigurava Nacionalna i sveučilišna knjižnica u Zagrebu. Knjižnica osigurava djelatnike i rad Ureda, posreduje pri sklapanju sporazuma između nakladnika i Crossrefa pružajući administrativno-pravnu podršku kao i tehničku podršku za izvršavanje obveza nakladnika.

Tehnička podrška, Sustav DOI-HR, ${ }^{4}$ nakladnicima osigurava neprekidnu podršku za izračun jedinstvenog DOI-ja, registraciju DOI-ja, dostavu novih ili osuvremenjenih metapodataka te dostavu objekata za koje je DOI registriran. Sustav je ujedno i tehnička podrška za uvrštavanje metapodataka u Hrvatsku nacionalnu

\footnotetext{
1 Hrvatski ured za DOI. [citirano: 2019-05-13]. Dostupno na: http://www.nsk.hr/doi.

2 Crossref. [citirano: 2019-05-13]. Dostupno na: https://www.crossref.org/.

3 Dodjela/izračun DOI-ja postupak je određivanja jedinstvenog sufiksa unutar dodijeljenoga prefiksa. Nakladnik DOI sufiks može izračunavati samostalno ili korištenjem aplikacije Hrvatskog ureda za DOI. Registracija DOI-ja je aktivacija DOI-ja u Crossrefu koja se postiže slanjem metapodataka o objektu i dodijeljenoga DOI-ja odmah po objavi objekta

4 DOI-HR. [citirano: 2019-05-13]. Dostupno na: https://doi.nsk.hr/.
} 
bibliografiju, Niz $\mathrm{B}^{5}$ te objavu digitalne građe i pripadajućih metapodataka na portalu Digitalne zbirke Nacionalne i sveučilišne knjižnice u Zagrebu. ${ }^{6}$

Model djelovanja Ureda i suradnje s nakladnicima, osim zahtjevima međunarodnog sustava za DOI, prilagođen je potrebama hrvatskih nakladnika i njihovim specifičnostima. U radu se opisuju osnovna svojstva identifikacijskog sustava za DOI i njegove registracijske agencije Crossref da bi se rad temeljno posvetio opisu Crossrefovog registracijskog ureda u Republici Hrvatskoj - Hrvatskog ureda za DOI pri Nacionalnoj i sveučilišnoj knjižnici u Zagrebu - jedinoj nacionalnoj i jednoj od tri sveučilišne knjižnice u svijetu koje primjenjuju novi Crossrefov model zastupanja nakladnika (Sponsoring Organisation). ${ }^{7}$

Navođenjem statističkih podataka o tekućim hrvatskim znanstvenim i znanstveno-stručnim časopisima argumentiraju se razlozi osnivanja Ureda i pogodnosti članstva ostvarenog njegovim posredništvom. Statistički podaci temelje se na dugogodišnjem praćenju svojstava hrvatskih mrežnih znanstvenih i znanstveno-stručnih časopisa. Rad donosi statističke podatke o hrvatskim tekućim mrežnim znanstvenim i znanstveno-stručnim časopisima zabilježene krajem 2018. godine - njihov broj, redovitost izlaženja, mrežna mjesta na kojima se objavljuju, način uređivanja časopisa u odnosu na mjerila koja trebaju zadovoljavati za registraciju DOI-ja ${ }^{8}{ }^{k}$ ao i povećanje broja časopisa koji koriste DOI. Opisuje se radni proces Hrvatskog ureda za DOI, Sustav DOI-HR, njegova struktura, svrha, funkcionalnosti, modeli suradnje i načini dostave metapodataka, kao i njegova interoperabilnost s drugim sustavima.

Za potrebe ovog rada pod znanstvenim i znanstveno-stručnim časopisima smatraju se časopisi koji objavljuju sadržaje iz područja određenih grana znanosti, a članci im imaju oblik znanstvenog članka.

\section{Identifikacijski sustav za DOI}

DOI (Digital Object Identifier) je normirani identifikator (ISO 26324:2012) koji služi jedinstvenoj identifikaciji objekata u digitalnom okruženju. On je jedinstven, trajan i aktivan identifikator sa svojstvom razrješivosti koje mu osigurava tehnologija pod nazivom digital object architecture ili handle system ${ }^{9}$ na kojoj se

\footnotetext{
5 Hrvatska nacionalna bibliografija. Niz B: članci. [citirano: 2019-05-13]. Dostupno na: http:// bibliografija.nsk.hr/b/.

6 Digitalne zbirke Nacionalne i sveučilišne knjižnice u Zagrebu. [citirano: 2019-05-13]. Dostupno na: https://digitalna.nsk.hr/pb/.

7 Sponsors. [citirano: 2019-11-07]. Dostupno na: https://www.crossref.org/community/sponsors/

8 Publikacije kojima se dodjeljuje DOI. [citirano: 2019-05-13]. Dostupno na: https://www.nsk. $\mathrm{hr} / \mathrm{doi} / \# 11$.

9 The handle system. // IFLA. [citirano: 2019-10-30]. Dostupno na: https://www.ifla.org/ best-practice-for-national-bibliographic-agencies-in-a-digital-age/node/8791.
} 
temelji sustav za DOI te omogućuje da identifikator upućuje na sam objekt koji identificira. Sustav za DOI interoperabilnost DOI-ja osigurava ne samo u tehnološkoj kompatibilnosti s drugim sustavima već i u prihvaćanju teorijskih postavki drugih standarda. Tako se primjerice pri identifikaciji knjižne građe oslanja na standarde za ISBD i ISSN, njihove definicije objekata (knjige, serijske publikacije, zbornika s konferencije itd.) i elemenata metapodataka kao i na pravila razlikovanja jednog objekta od drugog (npr. promjene naslova). Svojstvo granularnosti mu dodatno osigurava i široko područje djelovanja jer može biti dodijeljen bilo kojem objektu ili njegovu sastavnom dijelu. Nakladnici, knjižnice, citatne baze podataka, istraživači i financijeri koriste ga za identifikaciju časopisa, knjiga, članaka, izvješća, poglavlja u knjigama, istraživačkih podataka itd.

Sustavom za DOI upravlja Međunarodna zaklada za DOI (International DOI Foundation $)^{10}$, a znanstvenim se sadržajima DOI dodjeljuje i registrira posredništvom agencije Crossref, jedne od deset registracijskih agencija Zaklade. Registracijske agencije imaju nadležnost nad različitim jezičnim i geografskim područjima, kao i vrstama objekata koje identificiraju. Crossref koji djeluje u ime PILA-e (Publishers International Linking Association, Inc.) omogućuje identifikaciju znanstvenih časopisa, knjiga, zbornika s konferencija, disertacija, izvješća, normi, baza podataka, preprinta, kao i različitih razina njihove granularnosti (članak, sveščić, sastavni dijelovi članka itd.). ${ }^{11}$

Crossref danas broji više od 13840 članova iz 118 zemalja $^{12}$ te sadrži preko 100 milijuna metapodatkovnih zapisa od kojih se $74 \%$ odnosi na članke ${ }^{13}$, a taj broj iz dana u dan raste. Njegova prednost pred drugim agencijama je što osim same registracije DOI-ja osigurava niz dodatnih usluga koje podižu razinu kvalitete i dostupnosti znanstvenih sadržaja kao što su unakrsno povezivanje bibliografskih bilježaka (Reference linking), provjera izvornosti rada (Similarity Check), praćenje citiranosti (Cited-by), pristup povijesti izmjena određenoga sadržaja (Crossmark) itd. Članstvo u Crossrefu nakladnik može ostvariti samostalno ili posredništvom registracijskoga ureda.

Mjerila koja časopis treba zadovoljavati za registraciju DOI-ja su dodijeljen ISSN, ${ }^{14}$ uređen prema preporukama Crossrefa i redovito objavljivanje cjelovitih tekstova članaka. U skladu s preporukama Crossrefa članci koji se identificiraju

\footnotetext{
10 The DOI system. [citirano: 2019-05-13]. Dostupno na: https://www.doi.org/.

11 Content registration: content types. [citirano: 2019-08-21]. Dostupno na: https://www.crossref.org/services/content-registration/.

12 Become a member. [citirano: 2019-08-21]. Dostupno na: https://www.crossref.org/membership/.

$13100,000,000$ records - thank you! [citirano: 2019-05-13]. Dostupno na: https://www.crossref. org/blog/100000000-records-thank-you/.

14 Journal title management. [citirano: 2019-08-21]. Dostupno na: https://support.crossref.org/ hc/en-us/articles/213123866-Journal-title-management.
} 
DOI-jem trebaju imati oblikovanu odredišnu stranicu s potpunim bibliografskim podacima, kao što su naslov, autor(i), sažetak, ključne riječi, pristup ili podatak o načinu pristupa cjelovitome tekstu. ${ }^{15}$

Crossref DOI prikazuje se u obliku trajne poveznice, a sastoji se od domene i oznake DOI. ${ }^{16}$ Oznaku DOI čine prefiks i sufiks međusobno odvojeni kosom crtom " / " Npr.: https://doi.org/10.7774/cevr.2016.5.1.19, gdje je https://doi.org domena, 10.7774 - prefiks, a cevr.2016.5.1.19 - sufiks.

Prefiks članu, prilikom učlanjenja, dodjeljuje Crossref, a strukturu sufiksa član određuje samostalno.

\section{Hrvatski ured za DOI}

Hrvatski ured za DOI nacionalni je registracijski ured koji djeluje na području Republike Hrvatske u ime registracijske agencije Crossref. Osnovna zadaća Crossrefovog registracijskog ureda je pružanje administrativne, pravne, tehničke i jezične podrške nakladnicima. Usluga Hrvatskog ureda za DOI namijenjena je nakladnicima hrvatskih tekućih mrežnih znanstvenih i znanstveno-stručnih časopisa za registraciju DOI-ja samom časopisu, njegovim člancima i prema potrebi sveščićima i godištima. Dugoročno je u planu i proširenje opsega registracije DOI-ja na druge vrste znanstvenih sadržaja, kao što su zbornici s konferencija, knjige i dr.

\subsection{Pogodnosti članstva ostvarenog posrednišstvom Hrvatskoga ureda za DOI}

Do osnivanja Hrvatskog ureda za DOI svaki nakladnik je samostalno ostvarivao članstvo u Crossrefu, plaćao godišnju članarinu u iznosu od 275 \$, 1 \$ po registraciji DOI-ja za tekuću i prethodne dvije godine te $0,15 \$$ po registraciji DOI-ja za članke starijih godišta. Hrvatski ured za DOI plaćanjem jedne članarine u iznosu od 275 \$ pokriva članstvo u Crossrefu svim nakladnicima koji uslugu koriste posredništvom Ureda. Troškove registracije DOI-ja u tekućoj godini nije moguće smanjiti, no oni su pokriveni sredstvima Ministarstva znanosti i obrazovanja Republike Hrvatske.

Potreba za osnivanjem Hrvatskog ureda za DOI najjasnije se očituje u povećanju broja hrvatskih mrežnih znanstvenih i znanstveno-stručnih časopisa koji koriste DOI. Tako je 2013. godine prema podacima Crossrefa DOI koristilo 18 nakladnika za 21 naslov hrvatskih mrežnih znanstvenih i znanstveno-stručnih ča-

15 Your landing page. [citirano: 2019-08-21]. Dostupno na: https://support.crossref.org/hc/enus/articles/214669863-Your-landing-page; vidi i Membership therms. h) Maintaining and updating metadata [citirano: 2019-08-21]. Dostupno na: https://www.crossref.org/membership/terms/. 16 Crossref DOI display. [citirano: 2019-08-22]. Dostupno na: https://www.crossref.org/ display-guidelines/. 
sopisa, 2016. godine 58 nakladnika za 86 časopisa, 2017. godine 98 nakladnika za 120 naslova. U rujnu 2019. godine DOI koriste 142 nakladnika za 256 časopisa od toga 76 nakladnika za svojih 105 časopisa posredništvom Ureda (slika 1).

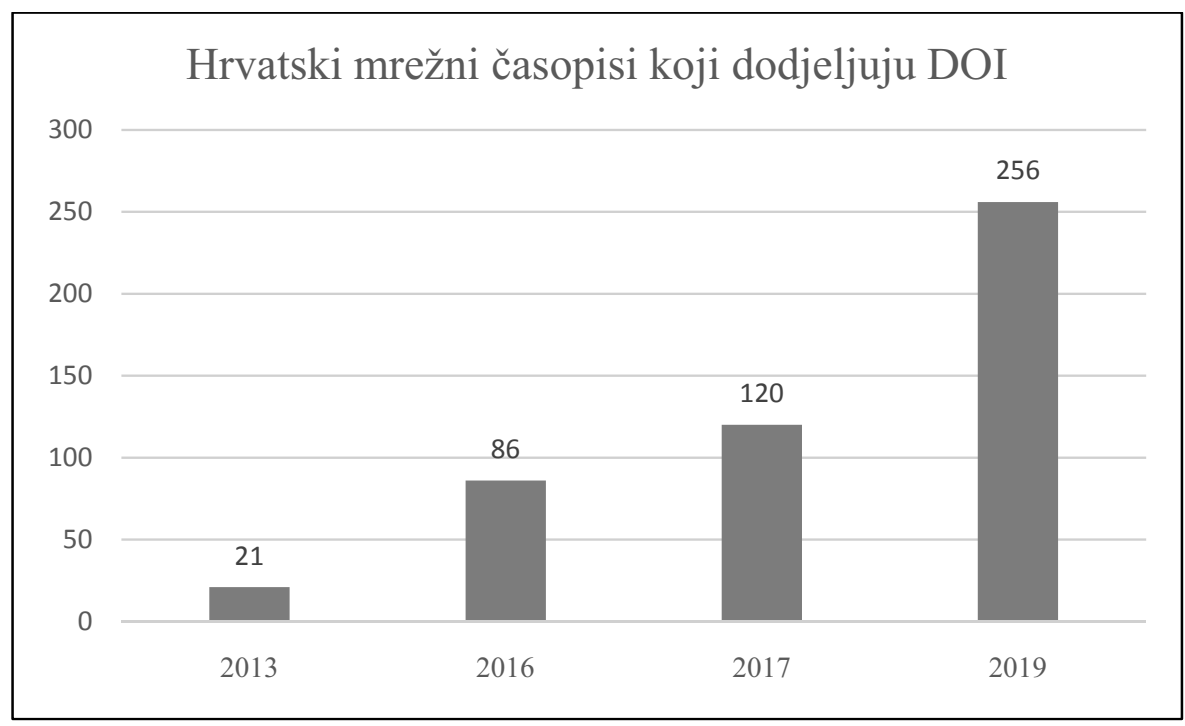

Slika 1. Rast broja hrvatskih mrežnih časopisa koji dodjeljuju DOI

Osim povećanja broja časopisa koji koriste DOI, u svrhu praćenja potrebe i mogućnosti osnivanja nacionalnog ureda za DOI pri Nacionalnoj i sveučilišnoj knjižnici u Zagrebu provodila su se dugogodišnja praćenja svojstava hrvatskih mrežnih znanstvenih i znanstveno-stručnih časopisa koja se odnose na njihov broj, redovitost izlaženja, mrežna mjesta na kojima se objavljuju te na način uređivanja u odnosu na preporuke Crossrefa, odnosno na postojanje propisno uređene odredišne stranice svakog članka. ${ }^{17}$

Tako krajem 2018. godine 260 nakladnika objavljuje ukupno 380 naslova hrvatskih tekućih mrežnih znanstvenih i znanstveno-stručnih časopisa.

Časopisi se uglavnom objavljuju na vlastitim mrežnim stranicama časopisa, odnosno nakladnika te na portalu Hrčak. Samo na vlastitoj stranici objavljuje se $12,10 \%$ (46) časopisa, a samo na portalu Hrčak 37,36 \% (142) časopisa. Najveći broj časopisa, odnosno njih 50,52\% (192), objavljuje se istovremeno i na vlastitim stranicama i na portalu Hrčak. Također, utvrđeno je da se mali broj časopisa, njih 2,89 \% (11), osim na vlastitim stranicama i portalu Hrčak dodatno objavljuje i na

17 Getliher, D. Tekući hrvatski mrežni časopisi i njihova svojstva. Zagreb: Nacionalna i sveučilišna knjižnica, 2018. [interni dokument] 
drugim platformama za objavu u znanstvenih časopisa kao što su Taylor \& Francis ${ }^{18}$, De Gruyter ${ }^{19}$, Brepols online ${ }^{20}$, JSTOR ${ }^{21}$, Central and Eastern European Online Library $(\mathrm{CEEOL})^{22}$, Econ Papers ${ }^{23}$, Ideas ${ }^{24}$ itd. (slika 2).

\section{Mrežna mjesta objavljivanja časopisa} Istovremeno stranice nakladnika i portal
Hrčka

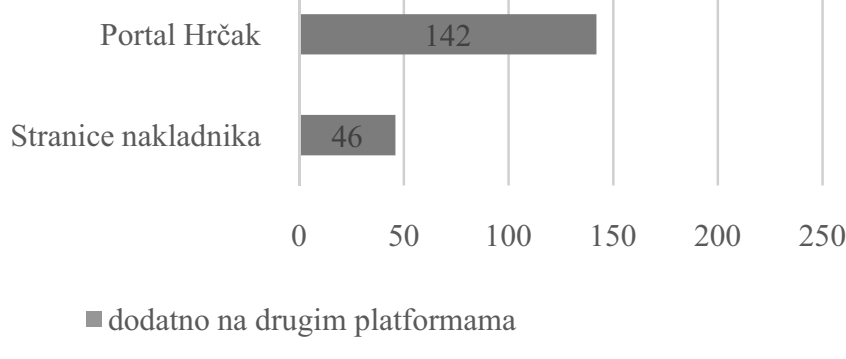

Slika 2. Prikaz mrežnih mjesta objavljivanja hrvatskih znanstvenih i znanstveno-stručnih časopisa

Od 380 naslova 9,21\% (35) izlazi samo na mreži, 90,98\% (345) ima izdanje na drugom mediju, a 2,36 \% (9) na mreži objavljuje i drugo jezično izdanje. Redovitost izlaženja, za koju se za potrebe ovog rada smatra objavljivanje većine sveščića godišta tekuće kalendarske godine, postiže 28,42 \% (108) naslova. Odredišnu stranicu, sukladno preporukama Crossrefa, imaju svi časopisi koji se objavljuju na Hrčku (334) te 85 časopisa koji se objavljuju na vlastitim mrežnim stranicama. Od 192 časopisa koji se objavljuju i na svojim stranicama i na Hrčku, na svojim stranicama odredišnu stranicu oblikuje samo 68 naslova. Zanimljivo je primijetiti da 16 naslova redovitije objavljuje sadržaje časopisa na vlastitim stranicama, 22 na stranicama Hrčka, dok ostali sadržaje časopisa na obje lokacije objavljuju istovremeno. Ove vrijednosti promjenjive su prirode, no u kraćim vremenskim raz-

18 Taylor \& Francis. [citirano: 2019-05-13]. Dostupno na: https://taylorandfrancis.com/.

19 De Gryuter. [citirano: 2019-05-13]. Dostupno na: https://www.degruyter.com/.

20 Brepols Online. [citirano: 2019-05-13]. Dostupno na: https://www.brepolsonline.net/.

21 JSTOR. [citirano: 2019-05-13]. Dostupno na: https://www.jstor.org/.

22 Central and Eastern European Online Library (CEEOL). [citirano: 2019-05-13]. Dostupno na: https://www.ceeol.com/.

23 Econ papers. [citirano: 2019-05-13]. Dostupno na: https://econpapers.repec.org/.

24 Ideas. [citirano: 2019-05-13]. Dostupno na: https://ideas.repec.org/. 
macima neće biti znatnih razlika koje bi upućivale na konkretne zaključke. Stoga će se navedeni parametri nastaviti pratiti i uspoređivati i u narednim godinama.

Jedan od razloga za osnivanje Ureda ujedno su i pogodnosti članstva. Pogodnosti članstva mogu se promatrati kao pogodnosti pojedinog nakladnika i/ili cjelokupne znanstvene zajednice. Najuočljivija je materijalna ušteda svakog pojedinog nakladnika na godišnjim članarinama. Tako godišnja članarina Hrvatskog ureda za DOI u iznosu od 275 \$ godišnja članarina za korištenje usluge provjere izvornosti rada (Similarity Check) u iznosu od 55 \$ pokrivaju članstvo u Crossrefu svim nakladnicima koji članstvo ostvaruju posredništvom Ureda. Osim troškova godišnjih članarina Ured sredstvima Ministarstva znanosti i obrazovanja Republike Hrvatske pokriva i troškove pojedinačnih registracija DOI-ja. Jedini troškovi koje nakladnik osigurava iz vlastitih sredstava su troškovi provjere izvornosti rada po dokumentu, kao i druge dodatne usluge.

Nakladnicima je osigurano korištenje vlastitog prefiksa te zadržavanje ranije korištenoga prefiksa i sufiksa prilikom prelaska u nadležnost Ureda, ukoliko je početno članstvo nakladnik prethodno ostvario samostalno. Osigurana im je tehnička podrška za dodjelu i registraciju DOI-ja, dostavu novih i osuvremenjenih metapodataka te dostavu objekata (PDF-ova članaka i sveščića) kroz korištenje Sustava DOI-HR. Nakladnicima je osigurana trajna pohrana registriranih članaka i sveščića jer je Nacionalna i sveučilišna knjižnica u Zagrebu registrirani arhiv za čuvanje i pohranu ovih objekata. Ujedno je ovo način osiguranja trajnosti DOIja. Naime, kada objekt nestaje s mreže DOI se preusmjerava na URL arhivskog primjerka. Dostavom objekata nakladnik istovremeno izvršava obvezu dostave obveznog primjerka i dobiva prednost pri uvrštavanju u Hrvatsku nacionalnu bibliografiju, Niz B te prednost pri uvrštavanju i objavljivanju objekata na portalu Digitalne zbirke Nacionalne i sveučilišne knjižnice u Zagrebu.

Ured olakšava nakladnicima rad posredujući u komunikaciji s Crossrefom i Ministarstvom znanosti i obrazovanja Republike Hrvatske te pri plaćanju računa.

Pogodnosti je do rujna 2019. prepoznalo i posredništvom Ureda ostvarilo 76 nakladnika za 105 naslova časopisa koji su dodijelili i registrirali 3200 DOI-ja za znanstvene i znanstveno-stručne članke godišta za 2016., 2017., 2018. te 2019. godinu. Umjesto 76 članarina za 2019. godinu plaćena je jedna te je ostvarena ušteda u iznosu 154.600 kn koja će se proporcionalno povećanju broja učlanjenih nakladnika dodatno povećavati. Registracije DOI-ja i dalje samostalnim članstvom u Crossrefu ostvaruje 66 nakladnika za 151 naslov (slika 3). 


\section{Ostvarenje sporazuma hrvatskih nakladnika i identifikacijskog sustava za DOI}

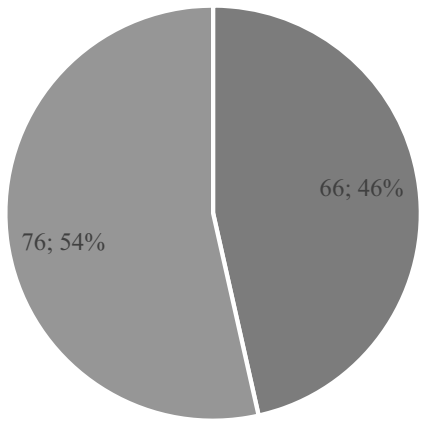

- samostalno = posredništvom Ureda

Slika 3. Način ostvarenja sporazuma hrvatskih nakladnika i identifikacijskog sustava za DOI

Ostvarenjem sporazuma s Crossrefom posredništvom Ureda omogućava se preusmjeravanje sredstava $s$ članarina na registracije DOI-ja i postizanje šireg obuhvata publikacija i radova hrvatskih znanstvenika s dodijeljenim DOI-jem. Posljedično se ostvaruju bolji preduvjeti za povezivanje i međunarodnu suradnju, bolje povezivanje u okviru kulturne i stručno-znanstvene suradnje, pripreme, pokretanja i vođenja istraživačkih i razvojnih međunarodnih programa i projekata uz doprinose integraciji u europski istraživački prostor te napretku istraživačke kompetitivnosti hrvatske znanstvene i nakladničke zajednice. Dugoročno se osigurava sveobuhvatnost okupljanja nacionalne znanstvene produkcije, olakšava izgradnja digitalne knjižnice, prikupljanje obveznog primjerka i izrada nacionalne bibliografije.

Zapreku za korištenje usluga Ureda i dalje imaju nakladnici koji osim za časopise DOI koriste i za identifikaciju drugih vrsta znanstvenih sadržaja, za koje Ured još ne osigurava uslugu, te nakladnici koji nemaju riješene pravne odnose sa svim svojim ograncima i podružnicama zbog čega nisu u mogućnosti prijeći u nadležnost Ureda. Naime, uvjet prelaska u nadležnost Ureda je prelazak nakladnika sa svim svojim naslovima za koje dodjeljuje i registrira DOI te potpisivanje sporazuma na najvišoj razini jedne institucije.

Dodatna, premostiva zapreka je nesigurnost i bojažljivost nakladnika u donošenju odluke o preuzimanju obaveza definiranih Sporazumom. 


\subsection{Radni proces Hrvatskog ureda za DOI}

Radni proces Hrvatskog ureda za DOI objedinjuje sve postupke dionika procesa, od djelatnika Ureda, nakladnika do ostalih suradničkih odjela Nacionalne i sveučilišne knjižnice u Zagrebu. Sam radni proces Ureda počinje postupkom učlanjenja nakladnika, odnosno potpisivanjem Sporazuma između nakladnika i Nacionalne i sveučilišne knjižnice u Zagrebu te, posredništvom Ureda, sporazuma nakladnika i Crossrefa (PILA Membership Agreement). U Sporazumu s Nacionalnom i sveučilišnom knjižnicom u Zagrebu nakladnik određuje naslove svojih časopisa za koje će dodjeljivati i registrirati DOI-je, odabire model suradnje, način dostave metapodataka i objekata te određuje način korištenja obveznog primjerka objekta. Nakladniku po potpisivanju navedenih sporazuma Crossref dodjeljuju prefiks i korisničke podatke za Crossref, a Ured korisničke podatke za Sustav DOI-HR, pisane upute za korištenje Sustava te podroban opis radnog procesa u skladu s odabranim modelom suradnje i načinom dostave metapodataka i objekata.

Nakladnik, odnosno suradnik za DOI, sukladno odabranom modelu suradnje i načinu dostave metapodataka dodjeljuje i registrira DOI-je te dostavlja metapodatke i objekte. Pri tome mu se pruža podrška Ureda, provode redovne reklamacije vezane uz eventualne pogreške pri registracijama DOI-ja ili dostavi objekata.

Metapodaci o člancima časopisa koje je u Sustav DOI-HR dostavio suradnik za DOI prenose se iz Sustava DOI-HR u Integrirani knjižnični sustav Aleph (IKS). Hrvatska nacionalna bibliografija, Niz B provjerava i dovršava obradu nad zaprimljenim zapisima mrežnih članaka uvidom u članak dostupan na URL-u članka. Dodaju se elementi metapodataka kao što je UDK, izrađuje normativa autora itd. (slika 4).

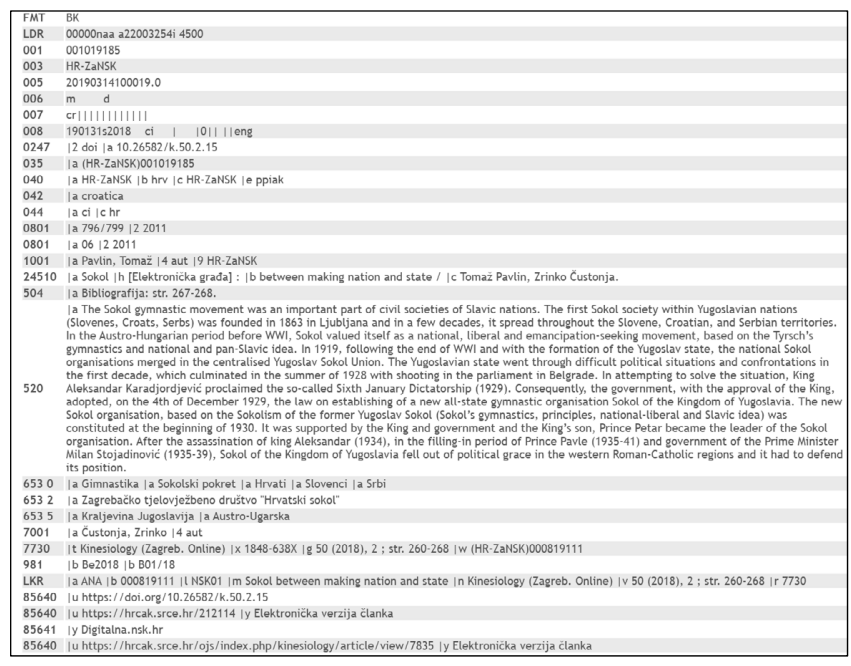

Slika 4. Zapis za članak Sokol, Kinesiology god. 50, br. 2, 2018. dovršen na Hrvatskoj nacionalnoj bibliografiji, niz B. ID zapisa u Katalogu NSK 1019185 
Dovršeni i ispravljeni zapisi mrežnih članaka se iz IKS-a preuzimaju u Sustav portala Digitalne zbirke Nacionalne i sveučilišne knjižnice u Zagrebu putem ID broja i nadograđuju konceptima. Također, preuzimaju se i dorađuju zapisi za autore iz normativne baze te nadopunjuju konceptima u Indigu (mjesto rođenja, smrti, dodaje se veza na VIAF, ISNI itd.). Sustav portala Digitalne zbirke Nacionalne i sveučilišne knjižnice u Zagrebu za preuzete zapise iz Alepha preuzima objekte tj. članke i sveščiće iz Sustava DOI-HR. (slika 5).

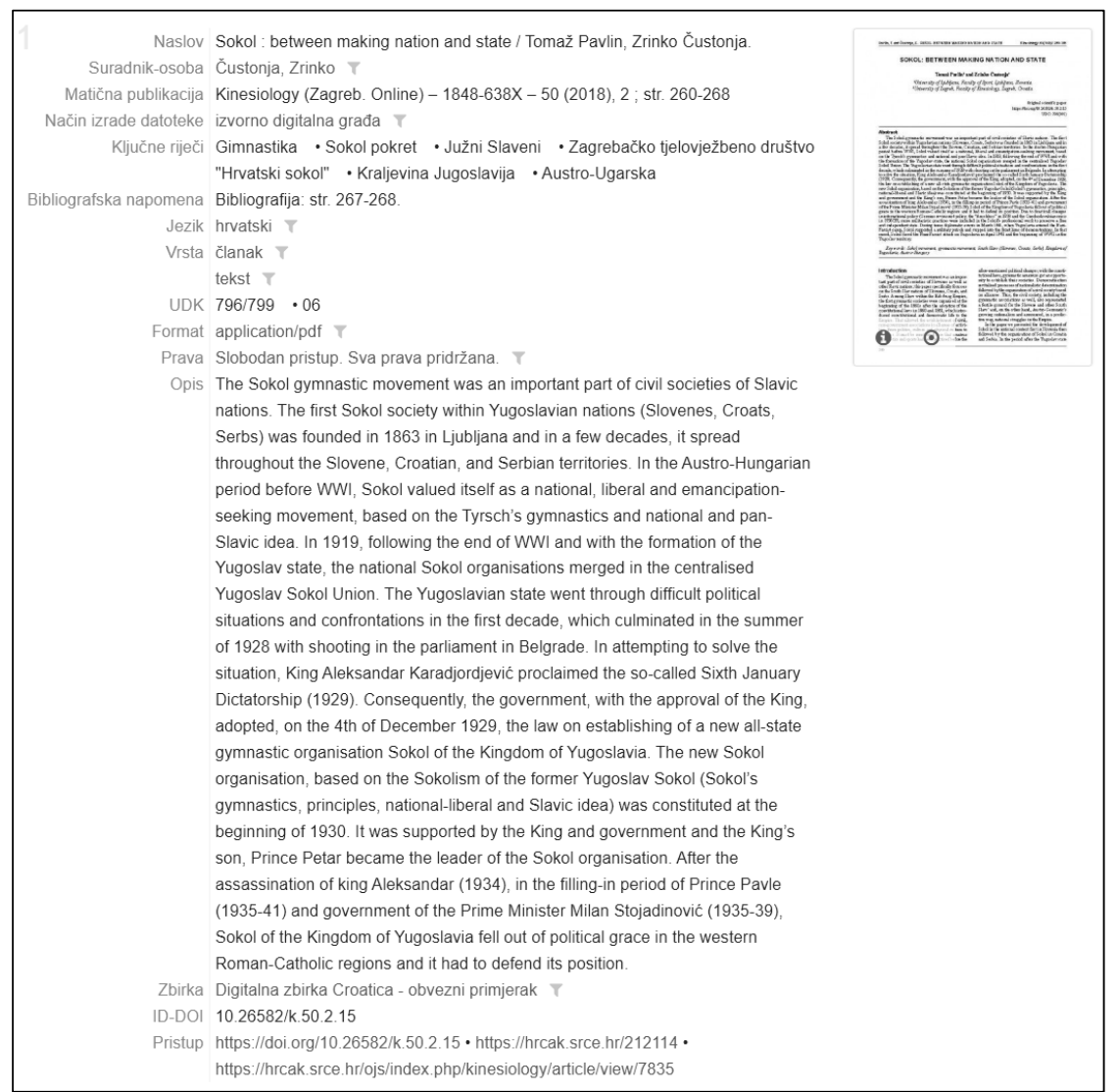

Slika 5. Zapis za članak Sokol, Kinesiology god. 50, br. 2, 2018. na portalu Digitalne zbirke Nacionalne i sveučilišne knjižnice u Zagrebu https://digitalna.nsk.hr/pb/?object=list\&find $=$ sokol\&mr\%5B549152\%5D=a

Osim zadataka koje izvršava kroz Sustav DOI-HR, nakladnik je dužan samostalno izvršavati zadatke unakrsnog povezivanja bibliografskih bilješki s pripadajućim DOI-jem koje se provodi kod uredničkog postupka uoči objave. 


\section{Sustav DOI-HR}

Hrvatski ured za DOI, kao registracijski ured za DOI, obvezan je ispunjavati svoje obveze definirane sporazumom s Crossrefom. Jedna od osnovnih obveza je osiguranje tehničke podrške za izvršavanje zadaća nakladnika koji članstvo u Crossrefu ostvaruju posredništvom Ureda. Prilikom donošenja odluke o tehničkom rješenju uzelo se u obzir nekoliko važnih čimbenika, a to su: zadaće međunarodnog identifikacijskog sustava za DOI, zadaće i potrebe nakladnika, zadaće registracijske agencije Crossref, zadaće Hrvatskog ureda za DOI kao registracijskog ureda te zadaće koje proizlaze iz temeljne djelatnosti Nacionalne i sveučilišne knjižnice u Zagrebu kao nacionalne knjižnice Republike Hrvatske i središnje knjižnice Sveučilišta u Zagrebu. Osim navedenoga, bilo je neophodno da tehničko rješenje zadovoljava uvjet interoperabilnosti, odnosno mogućnost razmjene podataka s drugim sustavima te uvjet mogućnosti prilagodbe i nadogradnje u skladu s potrebama razvoja identifikacijskog sustava. Kao rezultat toga nastao je Sustav DOI-HR ${ }^{25}$, dinamička mrežna aplikacija koju je izgradila Nacionalna i sveučilišna knjižnica u Zagrebu. Sustav je izgrađen u skriptnom programskom jeziku PHP (PHP: Hypertext Preprocessor $)^{26}$ čija je primarna namjena upravo izgradnja dinamičkih mrežnih stranica i aplikacija te kao takav pruža niz mogućnosti kao što su izrada, uređenje i prikaz dinamičkih materijala, kontrola pristupa aplikaciji, povezivanje aplikacije s bazom podataka, dodavanje i uređivanje podataka s poslužitelja, prijenos datoteka kroz aplikaciju i brojne druge. ${ }^{27}$

Razvoj korisničkog sučelja podrazumijevao je da korisnici Sustavu mogu pristupiti s različitih uređaja, koristeći različite operativne sustave i različite internet preglednike te da je prikaz prilagođen korisnicima - uredan, pregledan, jednostavan, intuitivan i lak za korištenje.

\subsection{Korisničko sučelje i funkcionalnosti Sustava DOI-HR}

Sustavu DOI-HR mogu pristupiti samo registrirani korisnici - učlanjeni nakladnici i djelatnici Hrvatskog ureda za DOI.

U sustav nakladnici mogu pristupiti svojim podacima koji uključuju naziv nakladnika, naziv nakladnika na drugom jeziku, službenu kraticu naziva nakladnika, godinu osnutka, OIB, adresu, kontakt podatke, ISBN prefiks, dodijeljeni DOI prefiks, ISNI itd., koji se temelje na Bazi ISBN-a hrvatskih nakladnika.

Metapodaci o časopisu temelje se na kataložnom zapisu kataloga Nacionalne i sveučilišne knjižnice u Zagrebu, a time i međunarodnim standardima za izradbu kataložnog opisa te ih niti nakladnik, niti djelatnik Ureda nemaju ovlasti mijenjati

25 DOI-HR. Nav. dj.

26 PHP. [citirano : 2019-08-21]. Dostupno na: https://www.php.net/.

27 Powers, D. PHP solutions: dynamic web design made easy. 2nd ed. New York: Apress, 2010., str. 1-5. 
u Sustavu. U slučaju potrebe za izmjenom podataka o časopisu, djelatnici Ureda obvezni su kontaktirati ISSN ured za Hrvatsku. Podaci o časopisu sadrže naslov i podnaslov časopisa, ključni i skraćeni ključni naslov časopisa, ISSN (Online), ISSN (Print) i ISSN-L, CODEN, URL-ove na kojima je časopis dostupan, URL s portala Digitalne zbirke Nacionalne i sveučilišne knjižnice u Zagrebu, DOI naslova časopisa i odredišnu stranicu na koju DOI upućuje, naziv i sjedište nakladnika, početnu godinu i učestalost izlaženja itd.

Za razliku od podataka o časopisu, podatke o pojedinom godištu, sveščiću i članku u Sustav unosi sam nakladnik, pojedinačnim unosom ili učitavanjem datoteke s metapodacima. Metapodaci koje je potrebno dostaviti sadrže podatke obvezne za registraciju DOI-ja, izradbu kataložnog opisa i pohranu obveznog primjerka, ali i dodatne podatke koji obogaćuju opis pojedinog objekta. Podaci sadrže brojčanu oznaku godišta i sveščića, datume objavljivanja tiskanog i online izdanja sveščića i članka, podatke o uredniku sveščića, jezik, početnu i završnu stranicu sveščića i članka, naslov i podnaslov članka (na svim jezicima na kojima se navode u članku), kategorizaciju rada, URL-ove na kojima je članak dostupan, DOI članka i odredišnu stranicu na koju DOI upućuje, podatke o autorima, sažetak i ključne riječi itd. Unutar metapodataka o sveščiću i članku nakladniku je omogućena i funkcija dostave datoteke objekata u PDF-u kroz koju ispunjava svoju obvezu dostave obveznih primjeraka digitalne inačice časopisa.

Osim unosa podataka i dostave digitalnih objekata, nakladnicima je dostupna i funkcija izračuna jedinstvenog sufiksa DOI-ja koji se izračunava temeljem brojčane oznake godišta i sveščića, a namijenjena je onim nakladnicima koji su prilikom učlanjenja odabrali potpunu tehničku podršku Ureda. Jednom izračunati DOI nakladnici ne mogu obrisati iz Sustava, a djelatnici Ureda to mogu napraviti samo do trenutka dok DOI nije registriran. Nakon unosa metapodataka o godištu, sveščiću i članku te nakon objave članka na mreži i navođenju DOI-ja na odredišnoj stranici, nakladniku se unutar metapodataka o članku nudi funkcija predaje zahtjeva za registraciju DOI-ja. Po primitku zahtjeva za registraciju DOI-ja djelatnici Ureda dodatno provjeravaju jesu li svi metapodaci obvezni za registraciju DOI-ja uneseni te ispravljaju ili nakladnika obavještavaju o potrebi ispravka nedostatnih podataka. Potpune zahtjeve djelatnici Ureda opcijom Aktiviraj DOI potom šalju u Crossref te DOI postaje aktivan kroz nekoliko minuta. Ovdje je važno naglasiti kako su nakladnici sami odgovorni za točnost unesenih metapodataka te djelatnici Ureda ne kontroliraju njihovu točnost, osim u slučaju odbijanja zahtjeva u Crossrefu.

Kroz izbornik korisničkog sučelja nakladnicima i djelatnicima Ureda dostupne su još dvije zajedničke funkcionalnosti - razmjena poruka i pohrana dokumenata. Kako je ranije navedeno, nakladnici i djelatnici Ureda kroz Sustav mogu međusobno razmjenjivati poruke i zaprimati sistemske poruke. Sve nepročitane poruke prikazuju se na početnoj stranici Sustava, a pročitane poruke se pohranjuju te im je kroz izbornik moguće pristupiti u svakome trenutku. Mogućnost razmjene po- 
ruka omogućila je da se Sustav DOI-HR koristi kao jedini komunikacijski kanal između nakladnika i Ureda, bez potrebe za telefonskom komunikacijom i komunikacijom e-poštom. Tako nakladnik na jednome mjestu ima uvid u svu ostvarenu komunikaciju s Uredom. Također, djelatnici Ureda u Sustav za svakog nakladnika pojedinačno pohranjuju dokumentaciju potpisanu pri učlanjenju u sustav za DOI, dopis s dodjelom ISSN-a mrežnoj inačici časopisa, Obavijest o razvrstavanju poslovnog subjekta prema NKD-u Državnog zavoda za statistiku i dr. Osim djelatnika Ureda, dokumente u Sustav može pohranjivati i sam nakladnik te svim pohranjenim dokumentima pristupiti u svakome trenutku.

Struktura i funkcionalnosti korisničkog sučelja dostupni djelatnicima Ureda nešto su većeg opsega od onih dostupnih učlanjenim nakladnicima (slika 6).

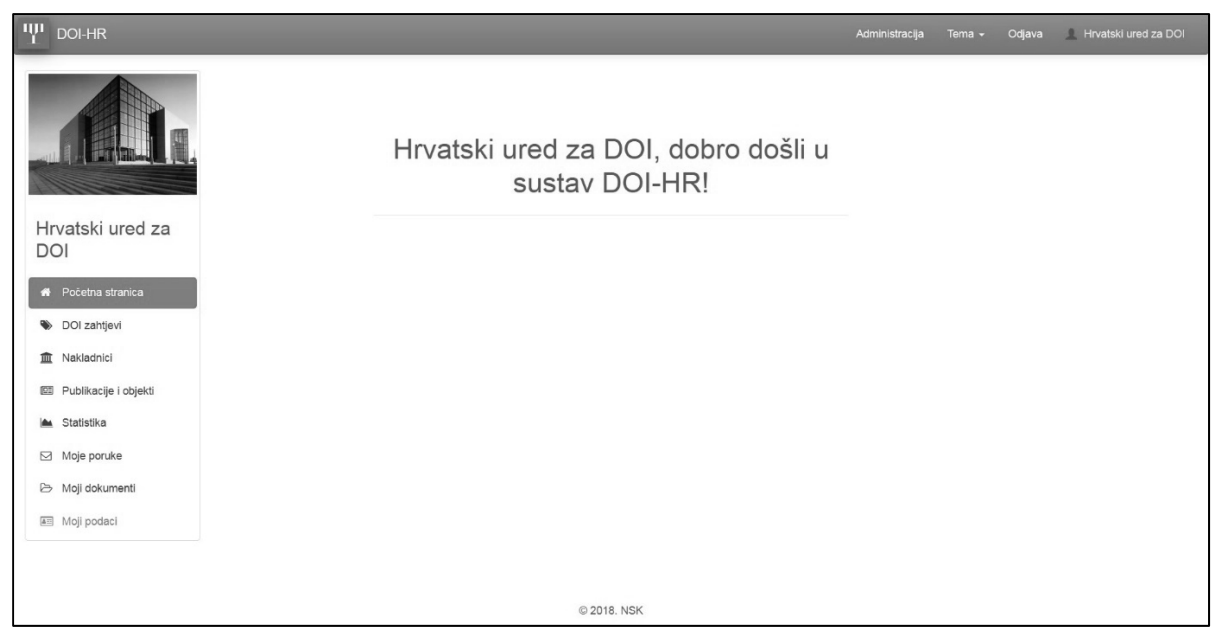

Slika 6. Korisničko sučelje Sustava DOI-HR - djelatnik Hrvatskog ureda za DOI

Kako je ranije navedeno, nakladnicima su dostupni samo vlastiti podaci o nakladniku i časopisu, dok su djelatnicima dostupni podaci svih učlanjenih nakladnika i njihovih časopisa. Također, djelatnici Ureda kroz izbornik sučelja imaju uvid u sve pristigle zahtjeve za registraciju DOI-ja. Lista pristiglih zahtjeva sadrži podatak o vrsti objekta za kojega je zahtjev predan, ISSN časopisa, naslov članka, dodijeljeni DOI, URL odredišne stranice na koju će DOI upućivati, ime osobe koja je zahtjev predala te datum predaje zahtjeva. Djelatnici tako pristigle zahtjeve mogu pregledavati i razvrstavati prema svim navedenim elementima, a pristupom pojedinome zahtjevu isti mogu odbiti, proslijediti u Crossref na aktivaciju ili zatražiti od nakladnika nadopunu metapodataka.

Kroz funkcionalnost praćenja statističkih podataka djelatnicima Ureda dostupan je uvid u statističke podatke o registriranim DOI-jima i dostavljenim obveznim primjercima. Podaci se mogu pregledavati prema nazivu nakladnika, naslovu 
časopisa i datumu registracije DOI-ja i/ili dostave objekata. Moguće je pristupiti ukupnim statističkim podacima kao i podacima za odabrano vremensko razdoblje.

Osim navedenih funkcionalnosti djelatnici imaju uvid u ostale informacije o Sustavu, kao što su statistički podaci o broju učlanjenih nakladnika i korisnika Sustava, broju časopisa, broju aktiviranih DOI-ja, veličini Sustava i sl., zatim uvid u XML-ove zaprimljene kroz aplikacijsko programsko sučelje, uvid u povijest izmjena Sustava te funkcionalnost dodavanja novih korisnika u Sustav.

\subsection{Modeli suradnje i način dostave podataka}

U nakladništvu hrvatskih mrežnih časopisa postoji veliki nesrazmjer u osiguranju financijskih i kadrovskih sredstava, osiguranoj tehničkoj podršci korištenoj kod uredničkih postupaka, objavljivanja i razmjene metapodataka. Neki časopisi godinama dodjeljuju i registriraju DOI-je i uvrštavaju metapodatke o svojim člancima u različite sustave, dok drugi nisu upoznati što je DOI i koje su prednosti njegova korištenja. Iz tih razloga Hrvatski ured za DOI nakladnicima nudi različite modele suradnje prilagođene različitim potrebama i posebnostima hrvatskih nakladnika. Ove specifičnosti očituju se u korištenju tehničke podrške, Sustava DOI-HR.

Sukladno potrebama i mogućnostima pojedinoga nakladnika, a koje se prvenstveno ogledaju u njihovoj potrebi za tehničkom podrškom pri korištenju usluge, Hrvatski ured za DOI nakladnicima nudi tri moguća modela suradnje. Model suradnje nakladnik odabire prilikom potpisivanja Sporazuma o učlanjenju u Crossref posredništvom Hrvatskog ureda za DOI, a u slučaju potrebe za promjenom odabranoga modela suradnje, potpisuje se novi aneks Sporazuma.

Odabirom modela suradnje nakladnik odabire želi li koristiti potpunu ili djelomičnu tehničku podršku pri izračunu/dodjeli DOI-ja, registraciji DOI-ja i dostavi metapodataka.

Prema Modelu 1 nakladnik koristi tehničku podršku Hrvatskog ureda za DOI za izračun/dodjelu DOI-ja odnosno njegovog jedinstvenog sufiksa, dostavu metapodataka i objekata, registraciju DOI-ja te osuvremenjivanje metapodataka. Ukoliko odabere Model 2, nakladnik preuzima brigu o izračunu jedinstvenog sufiksa, ali koristi tehničku podršku Hrvatskog ureda za DOI za dostavu metapodataka i objekata, registraciju DOI-ja te osuvremenjivanje metapodataka. Nakladnik koji je kao model suradnje odabrao Model 3 koristi vlastito tehničko rješenje za izračun i jedinstvenost sufiksa, slanje i osuvremenjivanje metapodataka i URL-ova i registraciju DOI-ja u Crossrefu, a u Sustav DOI-HR dužan je dostavljati registrirane DOI-je, metapodatke i objekte te osuvremenjivati metapodatke i URL-ove i u Sustavu DOI-HR odmah po dostavi istih u Crossref ili najkasnije do kraja tekućeg tromjesečja (tablica 1). 
Tablica 1. Obveze nakladnika prema odabranome modelu suradnje

\begin{tabular}{|l|c|c|c|}
\hline & MODEL 1 & MODEL 2 & MODEL 3 \\
\hline Izračun/dodjela jedinstvenog sufiksa & $\checkmark$ & X & X \\
\hline Registracija DOI-ja & $\checkmark$ & $\checkmark$ & X \\
\hline Osuvremenjivanje metapodataka & $\checkmark$ & $\checkmark$ & $\checkmark$ \\
\hline Dostavljanje (unos) metapodataka & $\checkmark$ & $\checkmark$ & $\checkmark$ \\
\hline Dostavljanje objekata & $\checkmark$ & $\checkmark$ & $\checkmark$ \\
\hline
\end{tabular}

Nakladnik je dužan dostavljati objekte svih znanstvenih i znanstveno-stručnih članaka za koje je registrirao DOI te cjeloviti sveščić u kojemu su ti članci objavljeni, a kao standardni format odabran je PDF. Ukoliko nakladnik ne objavljuje na mreži časopis u obliku cjelovitoga sveščića, dostavlja digitalnu matricu sveščića koju izrađuje radi objave časopisa u tiskanome obliku, na CD-u ili USB-u. Dostavom objekata nakladnik na ekonomičan način ispunjava svoju obvezu dostave obveznog primjerka digitalne inačice serijske publikacije.

Osim modela suradnje nakladnik prilikom učlanjenja odabire i željeni način dostave metapodataka i objekata u Sustav DOI-HR. Za sada su ponuđena dva načina dostave metapodataka i objekata: ručni i skupni unos. Ručni unos metapodataka pretpostavlja samostalno unošenje novih godišta, sveščića, članaka te pripadajućih im metapodataka i objekata od strane korisnika Sustava. S druge strane, nakladnici koji su kao način dostave metapodataka odabrali skupni unos, nova godišta, sveščiće, članke i pripadajuće im metapodatke i objekte dostavljaju u MODS XML-u. Metapodatkovna shema MODS razvijena je iz bibliografskog formata MARC 21 upravo za potrebe knjižnica te je odlikuju hijerarhijska struktura koja se sastoji od elemenata, podelemenata i atributa ${ }^{28}$ koji ih dodatno opisuju, zbog čega je odabrana kao najbolje rješenje za potrebe Sustava DOI-HR.

Osim ponuđenih načina dostave metapodataka i objekata u tijeku je testiranje razmjene metapodataka i objekata između Sustava DOI-HR i portala hrvatskih znanstvenih i stručnih časopisa Hrčak pri čemu se podaci iz Hrčka u Sustav također šalju u MODS-u. Budući da Sustav DOI-HR i Hrčak prikupljaju velik broj istih metapodataka kojima se opisuju znanstveni i znanstveno-stručni članci, dosadašnji rezultati testiranja pokazali su da je za uspješnu razmjenu podataka potrebna dodatna prilagodba oba sustava kako bi se osigurala dvosmjerna razmjena i veća točnost podataka.

28 Metadata Object Description Schema (MODS). [citirano: 2019-05-13]. Dostupno na: http:// www.loc.gov/standards/mods/. 


\subsection{Razmjena metapodataka Sustava DOI-HR i drugih sustava}

Kako bi se osigurala interoperabilnost s drugim sustavima, Sustav DOI-HR prilagođen je za preuzimanje podataka iz više drugih sustava, a radi podrške radnom procesu i drugih zahtjeva poslovanja omogućuje i drugim sustavima preuzimanje podataka (slika 7). Sustav DOI-HR u ovom trenutku ostvaruje jednosmjernu razmjenu metapodataka adresara nakladnika s Bazom ISBN-a hrvatskih nakladnika, dvosmjernu komunikaciju s registracijskom agencijom Crossref i Integriranim knjižničnim sustavom Aleph za razmjenu metapodataka o časopisima i člancima te jednosmjernu razmjenu metapodataka i objekata s portalom digitalnih zbirki Nacionalne i sveučilišne knjižnice u Zagrebu. ${ }^{29}$ Također, u tijeku je testiranje razmjene metapodataka i objekata s portalom hrvatskih znanstvenih i stručnih časopisa Hrčak čija bi uspješna provedba rezultirala bržim i jednostavnijim radnim procesom dodjele i/ili registracije DOI-ja. Zahvaljujući svojoj interoperabilnosti Sustav DOI-HR omogućuje uvrštavanje dostavljenih metapodataka o člancima u Hrvatsku nacionalnu bibliografiju, Niz B te njihovo objavljivanje na portalu Digitalne zbirke Nacionalne i sveučilišne knjižnice u Zagrebu.

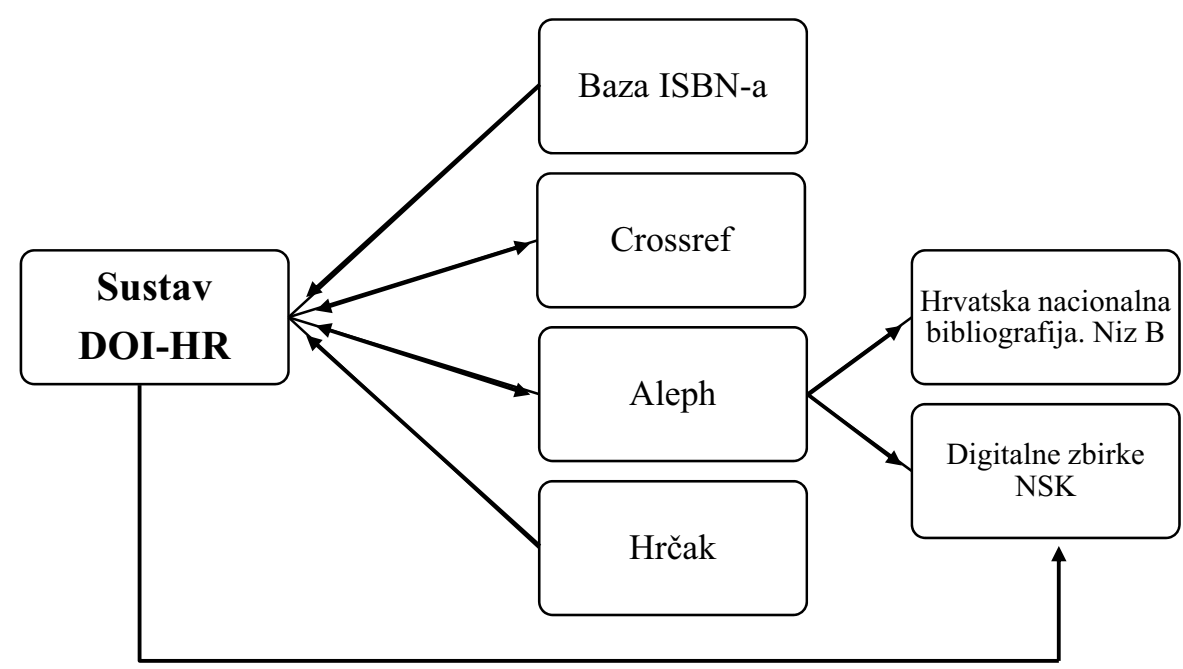

Slika 7. Razmjena metapodataka i objekata između Sustava DOI-HR i drugih sustava

Sustav DOI-HR se, sukladno razvoju međunarodnog sustava za DOI, ali i zahtjevima i uvjetima koje Sustav mora zadovoljiti kako bi se nakladnicima olakšalo

29 Baza ISBN-a hrvatskih nakladnika interna je baza Hrvatskog ureda za ISBN čiji se sadržaj jednom godišnje uvrštava i objavljuje u Međunarodnom imeniku nakladnika $=$ Global Register of Publishers (GRP) https://grp.isbn-international.org/. 
korištenje dodatnih usluga registracijske agencije Crossref, redovito dograđuje i osuvremenjuje novim funkcionalnostima i elementima metapodatka. Osim toga Sustav DOI-HR usklađuje se s potrebama drugih sustava s kojima razmjenjuje podatke. Tako se od početka 2019. godine započelo i s prikupljanjem podatka o URL-u cjelovitoga teksta rada, podatka neophodnog za korištenje Crossrefove dodatne usluge provjere izvornosti rada (Similarity Check), a u tijeku je i implementacija metapodataka za dostavu bibliografskih bilježaka koji su preduvjet za korištenje dodatne usluge praćenja citiranosti (Cited by).

\section{Zaključak}

Osnivanjem Hrvatskog ureda za DOI Nacionalna i sveučilišna knjižnica u Zagrebu osigurala je hrvatskim nakladnicima znanstvenih sadržaja korištenje još jednog, nezaobilaznog, identifikatora u digitalnom okruženju i nakladništvu 21. stoljeća. Djelovanje Ureda osiguralo je nakladnicima mnoge administrativne, tehničke, pravne i financijske pogodnosti. Hrvatski ured za DOI plaćanjem jedne godišnje pokriva troškove članstva svim nakladnicima koji koriste uslugu posredništvom Ureda. Time je posredništvom Ureda hrvatskoj znanstvenoj zajednici samo u 2019. godini ostvarena ušteda u iznosu od 154.600 kn, koja će povećanjem broja članova nadalje rasti.

Nakladnicima koji članstvo u Crossrefu ostvaruju posredništvom Ureda osiguran je novi model članstva u Crossrefu koji omogućava korištenje zasebnoga prefiksa te zadržavanje ranije korištenoga prefiksa i sufiksa prilikom prelaska u nadležnost Ureda. Osigurana im je tehnička podrška kroz mrežnu aplikaciju Sustav DOI-HR koja predstavlja jedinstveni sustav za izračun/dodjelu i registraciju DOI-ja, dostavu novih i osuvremenjenih metapodataka i izvršavanje drugih zadaća nakladnika i nacionalne knjižnice kao što su dostava i zaprimanje obveznog primjerka, uvrštavanje registriranih članaka u Hrvatsku nacionalnu bibliografiju, Niz B i uvrštavanje u digitalnu knjižnicu. Nakladnicima je osigurana trajna pohrana registriranih članaka, a time i trajnost DOI-ja u slučaju nestanka članaka s mreže.

Sustav ostvaruje razmjenu podataka s Crossrefom, Integriranim knjižničnim sustavom Aleph, razmjenu metapodataka i objekata s portalom Digitalne zbirke Nacionalne i sveučilišne knjižnice u Zagrebu, portalom hrvatskih znanstvenih i stručnih časopisa Hrčak te razmjenu s Bazom ISBN-a hrvatskih nakladnika.

Sustav DOI-HR se redovno osuvremenjuje i nadograđuje sukladno novim funkcionalnostima, uslugama i zahtjevima identifikacijskog sustava. Planira se razvoj i dorada Sustava koji će omogućiti prihvat metapodataka i u drugim formatima te automatizirati njihova razmjena s drugim sustavima. Time bi se prvenstveno nakladnicima koji objavljuju na portalu Hrčak omogućila dostava metapodataka posredništvom Hrčka i Sustavu DOI-HR preuzimanje ispravljenih i dopunjenih 
metapodataka iz Hrvatske nacionalne bibliografije, Niz B i njihovo ponovno slanje u Crossref.

Dugoročno se planira proširenje opsega korištenja DOI-ja na druge vrste znanstvenih sadržaja kao što su zbornici s konferencija, knjige i sl., čime bi se postigle još veće uštede te širi obuhvat publikacija i radova hrvatskih znanstvenika s dodijeljenim DOI-jem. Time se ostvaruju bolji preduvjeti za povezivanje u okviru kulturne i stručno-znanstvene suradnje, pripreme, pokretanja i vođenja istraživačkih i razvojnih međunarodnih programa i projekata uz doprinose integraciji u europski istraživački prostor te napretku istraživačke kompetitivnosti hrvatske znanstvene i nakladničke zajednice. Dugoročno se olakšava postizanje sveobuhvatnosti okupljanja nacionalne znanstvene produkcije, olakšava izgradnja digitalne knjižnice, prikupljanje obveznog primjerka i izrada nacionalne bibliografije.

\section{LITERATURA}

100,000,000 records - thank you! [citirano: 2019-05-13]. Dostupno na: https://www. crossref.org/blog/100000000-records-thank-you/.

Become a member. [citirano: 2019-08-21]. Dostupno na: https://www.crossref.org/ membership/.

Brepols Online. [citirano: 2019-05-13]. Dostupno na: https://www.brepolsonline.net/.

Central and Eastern European Online Library (CEEOL). [citirano: 2019-05-13]. Dostupno na: https://www.ceeol.com/.

Content registration: content types. [citirano: 2019-08-21]. Dostupno na: https://www. crossref.org/services/content-registration/.

Crossref. [citirano: 2019-05-13]. Dostupno na: https://www.crossref.org/.

Crossref DOI display. [citirano: 2019-08-22]. Dostupno na: https://www.crossref.org/ display-guidelines/.

De Gryuter. [citirano: 2019-05-13]. Dostupno na: https://www.degruyter.com/.

Digitalne zbirke Nacionalne i sveučilišne knjižnice u Zagrebu. [citirano: 2019-05-13]. Dostupno na: https://digitalna.nsk.hr/pb/.

DOI-HR. [citirano: 2019-05-13]. Dostupno na: https://doi.nsk.hr/.

The DOI System. [citirano: 2019-05-13]. Dostupno na: https://www.doi.org/.

Econ papers. [citirano: 2019-05-13]. Dostupno na: https://econpapers.repec.org/.

Getliher, Danijela. Tekući hrvatski mrežni časopisi i njihova svojstva. Zagreb: Nacionalna i sveučilišna knjižnica, 2018. [interni dokument] 
The handle system. // IFLA. [citirano: 2019-10-30]. Dostupno na: https://www.ifla.org/ best-practice-for-national-bibliographic-agencies-in-a-digital-age/node/8791.

Hrvatska nacionalna bibliografija. Niz B: članci [citirano: 2019-05-13]. Dostupno na: http://bibliografija.nsk.hr/b/.

Hrvatski ured za DOI. [citirano: 2019-05-13]. Dostupno na: http://www.nsk.hr/doi.

Ideas. [citirano: 2019-05-13]. Dostupno na: https://ideas.repec.org/.

Journal title management. [citirano: 2019-08-21]. Dostupno na: https://support.crossref.org/hc/en-us/articles/213123866-Journal-title-management.

JSTOR. [citirano: 2019-05-13]. Dostupno na: https://www.jstor.org/.

Membership therms. [citirano: 2019-08-21]. Dostupno na: https://www.crossref.org/ membership/terms/.

Metadata Object Description Schema (MODS). [citirano: 2019-05-13]. Dostupno na: http://www.loc.gov/standards/mods/.

PHP. [citirano: 2019-08-21]. Dostupno na: https:/www.php.net/.

Powers, D. PHP solutions: dynamic web design made easy. 2nd ed. New York: Apress, 2010.

Publikacije kojima se dodjeljuje DOI. [citirano: 2019-05-13]. Dostupno na: https:// www.nsk.hr/doi/\#11.

Sponsors. [citirano: 2019-11-07]. Dostupno na: https://www.crossref.org/community/ sponsors/.

Taylor \& Francis. [citirano: 2019-05-13]. Dostupno na: https://taylorandfrancis.com/.

Your landing page. [citirano: 2019-08-21]. Dostupno na: https://support.crossref.org/ hc/en-us/articles/214669863-Your-landing-page. 